
Nesta etapa foram coletados dados visando à compreensão da passagem natureza-cultura entre os humanos e à identificação do fio condutor interno ao conjunto de suas ações. Este relatório se restringe a apresentar alguns elementos que formam a confusão observada entre as unidades móveis Homo sapiens, ainda sem a pretensão de explicá-los. Para fins expositivos, selecionou-se relatos de observações diretas da conduta de duas unidades móveis previamente selecionadas segundo regras do método em vigor. São descrições assentadas parcialmente sobre dados colhidos nas incursões de um humano, identificado aqui apenas como Gti, a fim de que se possa manter em sigilo a sua identidade. Busca-se acompanhar o entrelaçamento de suas ações com as intervenções no mundo da vida efetivadas por uma outra unidade móvel, identificada como Gta. Adotamos Gti como o ponto-de-vista das descrições, não o contrário, pois a natureza da segunda unidade móvel é incognoscível segundo as categorias da Real Academia.

Muita vez absorto em uma tarefa sempre indigna para-nós, os providos de asas, Gti gosta de usar do corpo todo apenas uma das patas a rabiscar signos de tinta azul sobre superfícies de celulose por um longo período de tempo. O corpo imóvel realça a central nervosa indefesa, com sensores visuais acionados para baixo, os demais desligados para o mundo exterior, no geral pouco se importando com sinais de ataque de predadores, imprudência comum aos da sua espécie. Por mais de 12 horas Gti permanece envolvido com esses signos, tarefa sem sentido, pois já se tinha como escrito o "colóquio"

Certa vez, após o período inicial de levantamentos de dados sobre as condições ambientais e constatarmos que o clima era favorável a vôos noturnos, e como sem esforço não há ciência, seguimo-lo. Uma vez no habitat de Gta, sentava-se novamente. Detectou-se oscilações olfativas marcadas por uma estranha cumplicidade; variáveis químico-biológicas acionavam alterações na pressão arterial, dilatação das pupilas, alterações hormonais e variação na freqüência dos batimentos cardíacos.

Desatentos aos ruídos e cheiros, eram apenas cortesia e devota amabilidade mútua. Nesses encontros, o assunto da conversa era algo muito complexo para eles, e sem o menor sentido para-nós, insetos da Real Academia: "repercussões especulativas de 1848 na tarefa do intelectual"; "a apresentação do negativo do capital segundo seu conceito"; 


\section{Relatório de Pesquisa}

"a dança como linguagem e como atividade"; "composição da taxa de juros e a âncora cambial"; "o botim e desmonte economicista vulgar de um certo país periférico ao núcleo orgânico industrializado" (sic, sic, sic!).

Por vezes distraia-lhes a atenção a passagem de outros humanos, a comida a ser devorada e, não raro, um estranho ritual, muito difundido entre todas as unidades móveis da espécie: o ritual da conversa com o plástico. Um monotônico trinado metálico de sineta convoca um deles para se sentar numa cadeira e conversar com um cilindro plástico longilíneo esburacado nas pontas, seguro por uma das mãos na altura das orelhas e em direção da boca. Apesar de o mundo ao redor parecer deixar de existir, destaca-se que, à parte o uso da boca no ritual com o plástico, de vez em quando Gta emitia um olhar que comunicava aos presentes que o plástico fala algo importante, ou anuncia a chegada de intempéries, que não chegavam - os humanos são assim mesmo: anunciam tempestades que nunca desabam. Já nós, Insetos sócios das delícias de tudo que Deus deixa cair do céu, não perdemos nossa vida atrás de pistas falsas, o que torna cinzento de tão previsível o desabar do céu sobre nossas cabeças.

Certa vez houve $O$ beijo, uma singela troca de fluidos entre Gta e Gti, com efeitos colaterais imediatos. Um beijo é um fenômeno tão contingente quanto o nascer do sol. É quando nossos instrumentos podem detectar que os humanos não são de todo anomalias, pois acionam suas trombas e mucosas para se comunicarem para além da fala. A tromba Gta é bem maior que a de Gti. Seu maxilar envolve mais o dele que vice-versa. A carne em volta da boca, os lábios, tocam-se e se apertam. Os de Gti brincam mais molemente que os de Gta. Durante a troca de fluídos suas trombas se acariciaram com ternura e encantamento. Apesar disso, ao invés de permanecerem juntos, separam-se.

Suspeita-se que Gta possa sintetizar algum entorpecente mais potente que os fluídos sintetizados por Gti, pois as articulações das patas inferiores deste perdem a firmeza durante o beijo. Segundo as categorias aceitas, tanto Gti como também Gta exteriorizavam importantes alterações, o que complica tudo: apesar da força natural desse laço, pararam de se freqüentar. Não permaneceram um com o outro em razão de quais interditos? Como se sabe, o universo Gta é impróprio para insetos: Gti se afasta numa medida preventiva? 
Gta e Gti parecem sempre descontentes com o que fazem. Mesmo quando foram observadas altas taxas de complexidade na composição e rotação de suas energias, viram as costas e se separam. Certa noite, após conversarem por horas consecutivas, despediram-se às pressas e sem o "beijo", como se fosse chover, disseram-se "a gente se vê, não vai sumir", sorriram. Desde então se voltaram para si mesmos e substituíram os encontros por um ausentar-se a dois. Nota-se um separar-se que lhes dói mas sem o qual não vivem. Denominam esse estado de "escutar-se a si mesmo" Isso foi há meses.

Do que se observou pouco pode ser afirmado com segurança. É como se tudo o que quisessem fosse chegar a algo para depois abandoná-lo e depois retomá-lo e assim por diante, sempre. Há um contínuo atarefar-se com o que fazem misturado com uma sede de apagar tudo e recomeçar do nada, sem chegar ao nada inicial nem tampouco ao objetivo final, permanecendo num "entre" que nunca acaba. Haveria Universo, se, para tal, fosse preciso o operar dos humanos? 